\title{
The Influence of Sedentary Lifestyle on Low Back Pain and Lower Concentration Level
}

\author{
Karla Rožac ${ }^{1}$, Štefica Mikšićc ${ }^{2}$ \\ ${ }^{1}$ Department of Anatomy, Histology, Embryology, Pathological Anatomy and Pathological Histology, Faculty of Dental Medicine and \\ Health Osijek, Josip Juraj Strossmayer University, Osijek, Croatia \\ ${ }_{2}^{2}$ Department of Nursing and Palliative Medicine, Faculty of Dental Medicine and Health Osijek, Josip Juraj Strossmayer Univer- \\ sity, Osijek, Croatia
}

\begin{abstract}
Lower back pain is today the most common condition caused by a sedentary lifestyle. As it occurs more frequently at a younger age, this research was conducted to examine physical activity and lower back pain in students, and whether there are any correlations. The study surveyed 113 respondents using a survey questionnaire that included sociodemographic data, respondents 'attitudes about physical activity and lower back pain, and a visual analogue scale for pain assessment (VAS) and Oswestry's Quality of Life Questionnaire. The results of the research showed a statistically significant difference in concentration during learning and sleep quality in relation to sitting for several hours and performing activities of daily living, as well as the influence of pain. Considering that the study of nursing and physiotherapy from undergraduate to graduate level was compared, a significant difference was found in the total sum of the Oswestry questionnaire between these levels ( $p=0.003)$, while a positive correlation of mean strength was found between the results of this questionnaire $(\tau=0.448)$ and degree of pain. Hours of sitting and physical inactivity contribute to the development of pain. Physical activity and strengthening of the abdominal and back muscles, and proper change of position leads to the prevention of pain.
\end{abstract}

Key words: physical activity, low back pain, students, sedentary lifestyle

\section{Introduction}

Lower back pain is characterized by painful and in a functionally limiting condition of the person. It occupies a leading position in the kinds of problems caused by work or daily life disability, which represents a global economic and medical problem in people of different age ${ }^{1}$. The first symptoms may appear between the ages of 20 and 55 and depend on physical activity ${ }^{2}$. This pain can be classified according to duration, and divided into acute (lasts 0-6 weeks), subacute (6-12 weeks) and chronic (lasts longer than 12 weeks), while the cause of low back pain can be specific and nonspecific ${ }^{3,4}$. This condition is heterogeneous, which affects the way it is assessed, classified, and treated. The Croatian Vertebrological Society provides guidelines on how to prescribe and implement appropriate diagnostic and therapeutic procedures for patients with low back pain ${ }^{5}$. Treatment depends on the degree of the disease and may be conservative or operative ${ }^{6}$.

A healthy lifestyle today is only a recommendation, not an obligation, which is in a bad way part of the modern sedentary lifestyle, where the culture of living promotes a fast lifestyle on the one hand, and encourages physical inactivity on the other. International guidelines in the treatment of acute and chronic low back pain emphasize the importance of physical activity and exercise as the main strategies in prevention. Physical activity is any movement of the body that permeates all aspects of life. Optimal physical activity improves the quality of life, promotes recovery and secondary prevention, and, in addition, it has a positive effect on the psychological aspect of a person in order to reduce depression and anxiety and enables and encourages increased personal satisfaction ${ }^{2,5}$.

The aim of the research is to examine quality of life, physical activity, and pain in the lower back in students at the Faculty of Dental Medicine and Health Osijek, Department of Nursing and Physiotherapy.

\section{Materials and Methods}

The research was conducted at the Faculty of Dental Medicine and Health Osijek from March 2020 to April 2020. The inclusion criteria were the age of majority of the 
respondents and attendance at the undergraduate or graduate university study program of Nursing or Physiotherapy. Respondents were selected at random, every third respondent.

The study included a sample of 113 respondents, divided into groups: regularly physically active persons, persons who do not engage in regular physical activity, persons who do not have lower back pain and persons who have lower back pain.

All data were collected through an anonymous survey questionnaire consisting of 28 questions divided into 2 parts. The first 19 questions consist of general sociodemographic data, physical activity, and lower back pain. The Visual Analog Scale (VAS) was used, which offered respondents a personal assessment of 0 to 10 spinal pain, and the Oswestry questionnaire composed of 9 personally measurable categories was also used. Questionnaire on the quality of life of people with low back pain - OswestryThe questionnaire consisted of the following categories: clothing and footwear, lifting heavy loads, walking and running, sitting, standing, sleeping, social life and recreation, travel, and sex life. The answers were rated 1 to 6 , in which grade 1 represents a condition without pain or without limitation, and on the other side of gradation, grade 6 indicates no ability to perform activities or participate. This type of questionnaire is used in practice to determine the degree of disability and the problem of participation, so the Croatian form of the questionnaire is available and has proven to be valid, applicable and reliable 3,7 .

Interpretation of the index on the quality of life: $0-20 \%$ : minimal disability, 21-40\%: moderate disability, 41-60\%: severe disability, 61-80\%: severe disability, 81-100\%: complete disability ${ }^{3,8}$.

The data were statistically processed in computer program R (www.r-project.org, version 3.5.3). Descriptively, categorical variables are represented by absolute and relative frequencies, and numerical variables depending on the distribution of data by arithmetic mean and standard deviation, and by median and interquartile range. The normality of the distribution was examined using the Kolmogorov Smirnov test. The $\mathrm{X}^{2}$ test analyzed the differences between the categorical variables, and between the numerical Mann-Whitney U test and the Kruskal Wallis test. Correlation analysis was done using the Kendall $\tau$ test. The level of statistical significance was determined with $\mathrm{p}<0.05$.

\section{Results}

The research was attended by 113 respondents, of which $22(\mathrm{~N}=19.47 \%)$ are male and $91(\mathrm{~N}=80.53 \%)$ female, of these respondents - attending the university study of Nursing $51(\mathrm{~N}=45.13 \%)$ and university Physiotherapy study $62(\mathrm{~N}=54.87 \%)$ (Table 1$)$.

Table 2. shows the correlations of back pain with the habits of the respondents. The largest share of respon- dents report back pain at least once a month (39.82\%), and a total of $23.89 \%$ of respondents have pain at least once a week. There is a significant difference in the time spent sitting, where it is evident that most respondents (58.41\%) spend more than 3 hours a day sitting. Back pain disrupts the quality of life in $29.2 \%$ of respondents, in $22.12 \%$ of respondents disrupts the performance of obligations, and $21.24 \%$ of respondents report a disturbance in concentration during learning due to pain, and $27.43 \%$ report sleep disturbances due to pain.

\section{TABLE 1}

DISPLAY OF GENERAL DATA OF RESPONDENTS, FREQUENCY, DURATION AND TYPE OF PHYSICAL ACTIVITY

\begin{tabular}{lcc}
\hline \multicolumn{1}{c}{$\mathrm{n}(\%)$} & $\mathrm{p}^{*}$ \\
\hline Gender & & \\
Male & $22(19.47)$ & $<0.001$ \\
Female & $91(80.53)$ &
\end{tabular}

Degree of study

$\begin{array}{ll}\begin{array}{l}\text { Graduate study of Physiother- } \\ \text { apy }\end{array} & 32(28.32) \\ \text { Graduate study of Nursing } & 25(22.12) \\ \begin{array}{l}\text { Undergraduate study of } \\ \text { Physiotherapy }\end{array} & 30(26.55) \\ \begin{array}{l}\text { Undergraduate study of } \\ \text { Nursing }\end{array} & 26(23.01)\end{array}$

Frequency of physical activity

Not engaging physical activity

Once a month

$24(21.24)$

2-3 times a month

Once a week

9 (7.96)

$<0.001$

2-3 times in a week

$14(12.39)$

More than 3 times a week

36 (31.86)

$24(21.24)$

Duration of physical activity

$\begin{array}{ll}\text { up to } 35 \text { minutes } & 25(28.09) \\ 30-45 \text { minutes } & 27(30.34) \\ >45 \text { minutes } & 37(41.57)\end{array}$

Type of physical activity

$\begin{array}{lc}\text { Cycling } & 1(1.14) \\ \text { Group training } & 15(17.05) \\ \text { Individual traning } & 24(27.27) \\ \text { Football trening } & 1(1.14) \\ \text { Self-training at home } & 43(48.86) \\ \text { Self-training at gym } & 1(1.14) \\ \text { All of the above } & 1(1.14) \\ \text { P.E } & 1(1.14) \\ \text { Walks } & 1(1.14)\end{array}$

$<0.001$

$\mathrm{AM}(\mathrm{SD})$

Age

$23.31(5.1)$

Pain rating

$3.44(2.32)$

* $\mathrm{X}^{2}$ test, AM. -arithmetic mean, SD - standard deviation 
TABLE 2

CONNECTION BETWEEN LOW BACK PAIN WITH HABITS OF THE RESPONDENTS

\begin{tabular}{lcc}
\hline & $\mathrm{n}(\%)$ & $\mathrm{p}^{*}$ \\
\hline $\begin{array}{ll}\text { Have you ever had a spine problem? } \\
\text { Yes }\end{array}$ & $46(40.71)$ & 0.181 \\
No & $37(32.74)$ & \\
$\quad$ Sometimes & $30(26.55)$ & \\
How long do you spend sitting in a chair? & \\
$\quad<2$ h daily & $18(15.93)<0.001$ \\
2-3 h daily & $29(25.66)$ & \\
$>3$ h daily & $66(58.41)$
\end{tabular}

How often do you have problems with back pain?

$\begin{array}{lc}\text { No problem } & 21(18.58)<0.001 \\ \text { Once a month } & 45(39.82) \\ 2-3 \text { times a month } & 20(17.7) \\ \text { Once a week } & 8(7.08) \\ 2-3 \text { times a week } & 14(12.39) \\ >3 \text { times a week } & 5(4.42)\end{array}$

Do you feel that back pain affects your quality of life?

$\begin{array}{lcl}\text { Yes } & 33(29.2) & 0.631 \\ \text { No } & 41(36.28) & \\ \text { Sometimes } & 39(34.51) & \end{array}$

Do you feel that back pain affects the performance of your duties?

\begin{tabular}{|c|c|}
\hline Yes & $25(22.12)$ \\
\hline No & $49(43.36)$ \\
\hline Sometimes & $39(34.51)$ \\
\hline
\end{tabular}

Do you find that back pain disrupts your concentration while learning?

$\begin{array}{lcl}\text { Yes } & 24(21.24) & 0.004 \\ \text { No } & 53(46.9) & \\ \text { Sometimes } & 36(31.86) & \end{array}$

Do you find that back pain affects your quality of sleep?

$\begin{array}{lll}\text { Yes } & 31(27.43) & 0.005 \\ \text { No } & 54(47.79) & \\ \text { Sometimes } & 28(24.78) & \end{array}$

Did you have to use any of the following due to the increased back pain:

$\begin{array}{lc}\text { Physical therapy } & 3(2.65)<0.001 \\ \text { Meds } & 12(10.62) \\ \text { Massage } & 32(28.32) \\ \text { Voltaren cream } & 10(8.85) \\ \text { None of the above } & 56(49.56)\end{array}$

\footnotetext{
${ }^{*} \mathrm{X}^{2}$ test
}

TABLE 3

DISPLAY OF SCORING RESULTS OF THE OSWESTRY QUESTIONNAIRE

\begin{tabular}{lc}
\hline & $\mathrm{AM} \pm \mathrm{SD}$ \\
\hline Dressing and footwear & $1.4 \pm 0.82$ \\
Lifting heavy weight & $1.64 \pm 0.88$ \\
Walking and running & $1.7 \pm 1.24$ \\
Sitting & $2.1 \pm 1.35$ \\
Standing & $1.4 \pm 0.62$ \\
Sleeping & $1.71 \pm 1.24$ \\
Social life and recreation & $1.57 \pm 1.08$ \\
Travels & $1.46 \pm 0.79$ \\
Sex life & $1.43 \pm 1.06$ \\
Total sum & $14.37 \pm 6.51$ \\
\hline
\end{tabular}

$\mathrm{AM}$ - arithmetic mean, SD - standard deviation

The summary of the Oswestry questionnaire in Table 3. contains the categories of the Oswestry questionnaire. The average total sum of the questionnaire results was $14.37 \pm 6.51$.

The index of the Oswestry questionnaire is calculated by dividing the total number of marked points by 54 and multiplying by $100 ;$ - respondents marked each category of activities and participation with one number from 1 to 6 , and the total possible number of points is $54^{3}$.

The index is $26.611 \%$ and speaks of the percentage of disability, which in this case is moderate disability according to the published instructions (21-40\%), and the disability index is interpreted according to the previously mentioned interpreter in the methods.

The results of the Oswestry questionnaire, according to the most significant variables, are shown in Table 4. A significant statistical difference was found in the total sum of the Oswestry questionnaire by type of study ( $p=$ $0.003)$. The highest median was recorded in graduate subjects (16 (11-21)), and the lowest in undergraduate subjects $(9.5(9-13))$.

A statistically significant positive correlation of mean strength was found in the correlation between the results of the Oswestry questionnaire $(\tau=0.448)$ and the degree of pain (Table 4).

\section{Discussion}

The incidence of spinal pain problems, had a statistically significant difference according to the type of study that students attend and according to the degree of morbidity. Given the prevalence of females represented in the study, one-month back pain may start from the assumption that pain is associated with the menstrual cycle, but it is noticeable that 47 students report back pain several times a month. The research showed that some students 
TABLE 4

COMPARISON OF THE RESULTS OF THE OSWESTRY QUESTIONNAIRE ACCORDING TO THE MOST SIGNIFICANT VARIABLES

\begin{tabular}{|c|c|c|c|}
\hline & $\mathrm{AM}(\mathrm{SD})$ & MED (IQR) & $\mathrm{p}^{*}$ \\
\hline \multicolumn{4}{|l|}{ Gender } \\
\hline Female & $14.55(6.13)$ & $13(9-18)$ & \multirow[t]{2}{*}{0.165} \\
\hline Male & $13.64(8.04)$ & $10.5(9-14)$ & \\
\hline \multicolumn{4}{|l|}{ Degree of study } \\
\hline Graduate study of Physiotherapy & $12.66(4.86)$ & $11(9-14)$ & \multirow[t]{4}{*}{0.003} \\
\hline Unergraduate study of Physiotherapy & $15.17(6.35)$ & $13(10-19)$ & \\
\hline Undergraduate study of Nursing & $12.38(5.97)$ & $9.5(9-13)$ & \\
\hline Graduate study of Nursing & $17.68(7.82)$ & $16(11-21)$ & \\
\hline \multicolumn{4}{|l|}{ Frequency of physical activity } \\
\hline More than 3 times a week & $12.71(4.77)$ & $11(9-14)$ & \multirow[t]{6}{*}{0.102} \\
\hline Not engaging physical activity & $16.71(8.48)$ & $14.5(9-19.5)$ & \\
\hline $2-3$ times a week & $14.89(6.95)$ & $12(9.5-17.5)$ & \\
\hline $2-3$ times a month & $10.89(3.95)$ & $9(9-11)$ & \\
\hline Once a month & $17(5.83)$ & $17(13-23)$ & \\
\hline Once a week & $13(3.96)$ & $12.5(9-16)$ & \\
\hline \multicolumn{4}{|l|}{ Time spent sitting } \\
\hline More than 3 hours a day & $14.68(6.77)$ & $13(9-18)$ & \multirow[t]{3}{*}{0.247} \\
\hline $2-3$ hours a day & $13.1(6.3)$ & $11(9-14)$ & \\
\hline \multirow[t]{2}{*}{ Up to 2 hours a day } & $15.28(5.9)$ & $14.5(10-19)$ & \\
\hline & $\tau$ & & $\mathrm{p}^{*}$ \\
\hline Age & 0.095 & & 0.137 \\
\hline Pain rating & 0.448 & & $<0.001$ \\
\hline
\end{tabular}

*Kruskal Wallis test, $†$ Man Whitney U test, $\tau$ - Kendall tau, AM - arithmetic mean, SD - standard deviation, MED - median, IQR - interquartile range

encountered back pain, while previous studies like this recorded a higher incidence of back pain, and subsequently with limited activity due to pain, which is a worrying figure $^{9,10}$.

The analog visual scale is a subjective feeling of pain that is 3.44 in this study, and compared to that - a study conducted on medical students - it was $3.2^{11}$. Some studies suggest mechanisms by which exercise can prevent lower back pain because it: 1) strengthens the back muscles and increases torso flexibility; 2) increase the supply of muscles of the spine and joints of the spine and intervertebral discs, minimizing injuries and improving recovery; 3) improve mood and thus change the perception of pain. However, it is not clear which type and how many exercises should be performed ${ }^{12}$.

Spinal problems today can be broad-spectrum, but the biggest cause of pain is a sedentary lifestyle which is shown in this paper as a statistically significant difference. Data from a similar study examining the level of physical activity and the prevalence of low back pain by health professionals showed the presence of lower back pain caused by sitting for several hours ${ }^{2}$. Often the pain is caused by improper sitting and uncomfortable chair, which can also affect the concentration during learning. Compared to this study, in a study conducted on health care students in Turkey, most students experienced back pain at least once while learning in a sitting position. The results of the study, which examined the frequency of back pain and risk factors, show that participants experienced back pain. A higher incidence of low back pain was noted with prolonged sitting for more than 3 hours a day, also, in one study conducted on students, subjects complained of stool discomfort that after prolonged sitting causes back pain $9,10,13$.

In this study, respondents felt that sleep quality was not impaired due to back pain. The results of the study, which focused on sleep quality in medical students, are very similar to this, as less than half of the students were satisfied with their sleep quality. With aging, lower back pain is becoming more common, in addition - it is known that work is more often done sitting or in some other ir- 
regular body position, which can lead to the development of pain, and thus cause insomnia ${ }^{14,15}$.

It is worrying, however, that students often consume analgesics at their own risk, and physical therapy is used by only a fraction of respondents. A study conducted in a younger group of Poles (aged 10-19) showed that almost one tenth of the respondents took over-the-counter medications ${ }^{13}$.

Oswestry's questionnaire examines the quality of life and it actually determines the degree of personal disability. The average total in this study was $14.37 \pm 6.51$, and the students who participated in this study belong to II. degree $(21 \%-40 \%)$ of disability. Previous research has been conducted on the working age population, so one of them, conducted in Poland, found that pain in the lumbar spine is most often expressed by respondents who believe that it is associated with longer working hours. Oswestry's questionnaire focused only on quality of life confirmed III. and IV. the degree of disability in nurses, which which degrees showed the lowest results in a person's quality of life ${ }^{8}$.

A statistically significant positive correlation in this study was found in the degree of pain associated with the results of the Oswestry questionnaire $(\mathrm{p}<0.001, \tau=$ 0.448). A similar study, which looked at the association of non-specific lower back pain and sleep quality, emotional state and pain level, compared with the Oswestry questionnaire, also showed a significant correlation between the VAS scale and the Oswestry questionnaire $(p=0.003)$, and another study reported a statistically significant correlation between pain assessment and the Oswestry questionnaire $(\mathrm{p}<0.001)^{16,17}$.

\section{Conclusion}

Sedentary lifestyle in the form of sitting for several hours and performing activities of daily living with insufficient physical activity contribute to the development of pain in the lower back, which in turn affects the quality of sleep and concentration during learning. It follows from the above that lower back pain has a limiting effect on the performance of physical activity in the end and on the quality of life itself according to both types of studies that students attend. Therefore, today it is necessary to encourage young people to get involved in various types of sports-fitness programs to prevent or prevent the occurrence of lower back pain.

\section{R E F E R E N C E S}

1. BERKOVIĆ-ŠUBIĆ M, HOFMANN G, VUZEM B, Medica Jadertina, 49 (2019) 187. - 2. ŽILIĆ I, TUDOR A, RUŽIĆ L, Hrvatski Športskomedicinski Vjesnik, 32 (2017) 59. - 3. GRUBIŠIĆ M, HOFFMAN G, JURINIĆ A, Hrvatska komora fizioterapeuta. (Zagreb, 2011) - 4. GRAZIO S, Fizikalna i rehabilitacijska medicina, 25 (2013) 112. - 5. ANZULOVIĆ Š, SAJKO T, Fizioinfo. 25 (2015) 30. - 6. GRAZIO S, ĆURKOVIĆ B, VLAK T, BAŠ́IĆ KES V, JELIĆ M, BULJAN D, GNJIDIĆ Z, NEMIČIĆ T, GRUBIŠIĆ F, BORIĆ I, KAUZLARIĆ N, MUSTAPIĆ M, DEMARIN V, Acta Medica Croatica, 66 (2012) 259. - 7. BAGARIĆ K, JANKOVIĆ K, LAPOV D, Physiotherapia Croatica, 15 (2018) 11. - 8. MROCZEK B, ŁUBKOWSKA W, JARNO W, JARACZEWSKA E, MIERZECKI A, Annals of Agricultural and Environmental Medicine, 27 (2020) 36. doi: 10.26444/aaem/115180 - 9. CASAS AS, PATIÑO MSS, CAMARGO DML, Salud UIS, 48 (2016) 446. doi: 10.18273/revsal.v48n42016003. - 10. ANGGIAT PANJAITAN L, CHE HON WH, BAAIT SN,
Jurnal Pro-Life, 5 (2018) 677. doi:10.33541/pro-life.v5i3. - 11. DU JY, AICHMAIR A, SCHROEDER JE, KIELY PD, NGUYEN JT, LEBL DR, International Archives of Public Health and Community Medicine, 1 (2017) 1. doi:10.23937/iaphcm-2017/1710002. - 12. ATIKOVIC A, TABAKOVIC M, KOSTOVSKI Z, ZAHIROVIC J, DELAS KALINSKI S, BILALIC J, KURT A, Journal of Pain and Relief, 6 (2017) 290. doi:10.4172/2167-0846.1000290. — 13. YUCEL H, TORUN P, Bezmialem Science. 1 (2016) 12-18. doi:10.14235/BS.2016.618. - 14. KEDRA A, SITARSKI D, Ortopedia, traumatologia, rehabilitacja. 18 (2016) 31. doi:10.5604/15093492.1198840. — 15.ŽURA N, LAKTAŠIĆ-ŽERJAVIĆ N, DRAŽENOVIĆ J, MATIJEVIĆ A, Reumatizam, 63 (2016) 136. — 16. SRIBASTAV SS, PEIHENG H, JUN L, ZEMIN L, FUXIN W, JIANRU W, HUI L, HUA W, ZHAOMIN Z, PeerJ, 5 (2017) 3282. doi: 10.7717/ peerj.3282. - 17. HONGA SK, SHINB DC, Medical Hypotheses, (2020) 137. doi: 10.1016/j.mehy.2020.109562.

\section{K. Rožac}

Department of Anatomy, Histology, Embryology, Pathological Anatomy and Pathological Histology, Faculty of Dental Medicine and Health, Josip Juraj Strossmayer University Osijek, Crkvena 21, 31000, Osijek, Croatia

e-mail: krozac@fdmz.hr 


\section{UTJECAJ SJEDILAČKOGA NAČINA ŽIVOTA NA BOL U DONJEM DIJELU LEĐA I OPADANJE KONCENTRACIJE}

\section{S A Ž E T A K}

Bol u donjem dijelu leđa danas je najrasprostranjenije stanje uzrokovano sjedilačkim načinom života. Sve češće se pojavljuje u mlađoj životnoj dobi, stoga je provedeno istraživanje kako bi se ispitala tjelesna aktivnost i bolovi u donjem dijelu leđa kod studenata, te ima li međusobne povezanosti. Istraživanjem je ispitano 113 ispitanika pomoću anketnog upitnika koji je uključio sociodemografske podatake, stavove ispitanika o tjelesnoj aktivnosti i bolovima u donjem dijelu leđa, te vizualno analognu skalu za procjenu boli (VAS) i Oswestryjev upitnik o kvaliteti života. Rezultati istraživanja pokazali su da višesatno sjedenje i izvršavanje aktivnosti svakodnevnog života imaju statistički značajnu razliku, kao i sam utjecaj bolova na koncentraciju za vrijeme učenja te kvalitetu sna. Obzirom da je uspoređivan studij sestrinstva i fizioterapije od preddiplomskog do diplomskog studija, utvrđena je značajna razlika u ukupnom zbroju Oswestryjevog upitnika prema navedenim studijama $(p=0,003)$, također i pozitivna korelacija srednje snage u povezanosti s rezultatima navedenog upitnika $(\tau=0,448)$ i stupnja boli. Višesatno sjedenje i tjelesna neaktivnost pridonose razvoju bolova. Tjelesna aktivnost i jačanje trbušne i leđne muskulature, te pravilno mijenjanje položaja dovodi do preveniranja bolova. 